\title{
A Bibliography of Primary Sources by Some Eighteenth-Century Women Writers
}

\author{
María Jesús Lorenzo Modia \\ Universidade da Coruña
}

My aim in preparing the present listing was to meet a perceived need in the field of eighteenth-century English fiction. A comparative examination of the extant bibliographical studies on the works of Mary Davys, Eliza Haywood, Sarah Fielding and Frances Sheridan reveals a number of contradictions, attributable to the difficulty of access to the primary sources and the lack of reliable editions of most of their texts.

This bibliography is intended to provide the most accurate information available by recording as many variations and different editions as possible. The origin of the data is manifold, as the list of works cited shows; sources are indicated by means of the identification key that appears under the name of the author in the descriptions of the different items (e.g. Morgan), or occasionally that of the first author (e.g. Blain), unless otherwise stated (as, for instance, in the case of common scholarly abbreviations, eg. D.N.B.: Dictionary of National Biography or N.C.B.E.L.: New Cambridge Bibliography of English Literature). The information provided by the various revised secondary sources has been checked against the evidence gleaned from - or the assumptions based on bibliographical repertories and the many editions I have been able to examine.

Given the versatility of some of the writers, particularly Eliza Haywood, and the variety and scope of their works, the literary production of each has been divided by genre, thus providing background information on the different texts, although in some cases this is tentative. This division proved especially taxing in the case of Haywood, whose work includes fiction, essays and biography. Another difficulty arose with the subdivision of fiction into novels and short stories, as a result of the wavering conventions according to which fiction was categorized in the period. I have followed Mayo's (1962: 6) division of fiction into novels (when the texts contain more than 12,000 words) and novelettes (when they fall short of that figure). Lastly, whenever there is doubt over authorship, the titles appear between brackets. The place of publication is London unless otherwise indicated. 


\section{A. Mary Davys. NOVELS}

The Lady's Tale (1700). Davys in Works (1725) q.v. remarks that she rewrote it. McBurney (1959) reports that he has not found the edition of the first version, which the author claimed to have sold for three guineas. He suggests that Davys might be referring to The Fugitive, revised in extenso as The Merry Wanderer for her 1725 edition in Works; however, Backscheider (1987) states that it was revised as The Amours and later enlarged as The False Friend, q.v. Blain mentions that the manuscript that had been sold for three guineas in 1700 was the one published in 1704 as The Amours of Alcippus and Lucippe. The Lady's Tale (1725): a machine-readable transcript. Cambridge: Chadwyck-Healey, 1996.

The Amours of Alcippus and Lucippe. A Novel. Written by a Lady (Printed for James Round: 1704). According to Lonsdale (ed.) (1990) p. 102, she sold it for three guineas. The Fugitive (1705). Lonsdale says that Davys recounts her own experiences when arriving in England; completely revised to be included in Works as The Merry Wanderer according to McBurney (1959) 350n, q.v.; Blain adds that it was dedicated to Esther Johnson; "Humorous, loosely organized tale" N.C.B.E.L.

The Reform'd Coquet, or The Memoirs of Amoranda, A Novel (1724). 7 eds. by 1760 according to Backscheider in Todd ed. 1987; frequently reprinted according to Lonsdale; published by susbcription; N.C.B.E.L.: 1724, 1725, at least 8 eds. by 1785 : "Exemplary novel, humour, good characterization, plotting." The Reformed Coquet, a surprising novel, or: Memoirs of Amorande, or: A Fluttering Heart Caught at Last (1724). This last title is the one supplied by F. Morgan, p. 465. Sixth ed. University of Pennsylvania Library and published by Brown University Women Writers Project. The Reform'd Coquet (1725): a machine-readable transcript. Cambridge: Chadwyck-Healey, 1996.

\section{ANTHOLOGY}

The Works of Mrs. Davys: Consisting of, Plays, Novels, Poems, and Familiar Letters. Several of which never before Publish'd. In Two Volumes. London: Printed by $\mathrm{H}$. Woodfall at Elzevir's-Head, without Temple-Bar for the Author.1725 Including earlier texts: Backsheider's list unless otherwise stated. Day: published by suscription.

The Amours of Alcippus and Lucippe. 1704.

The Fugitive. 1705.

The Northern Heiress, or The Humours of York. 1716. (A comedy).

The Modern Poet. An ironic picture of a poor poet by nature jealous of his peers.

The Self-Rival: A Comedy. Blain, not performed.

The Merry Wanderer. 1725. Anecdotes of a series of houses visited, praise of Swift and

Ireland according to Blain; Spender, 1986, includes it without a date; revision of The

Fugitive according to McBurney (1959) 350n.

The Reform'd Coquet; a Novel. 1724. Vol. II.

The Lady's Tale. 1700. Vol. II. 
Familiar Letters Betwixt a Gentleman and a Lady. Vol. II. I have examined the facsimile edition of the copy held by the British Library (633.e.14) New York: Garland, 1973 in the collection Foundations of the Novel. Seminal contribution to our knowledge of the origins of the novel, although it stands in need of thorough textual revision. Familiar Letters betwixt a Gentleman an a Lady: a machine-readable transcript. Cambridge: Chadwyck-Healey, 1996.

The Cousins. According to McBurney (1959): $348 \mathrm{n}$.

The Cousins: A Novel. Vol. II. In 1732 it appeared as The False Friend, or The Treacherous Portuguese, q. v. (Spender, 1986, 123, includes it without a date as The Cousins: Familiar Letters Betwixt a Gentleman and a Lady); but this is clearly wrong, since Familiar Letters deals with the courtship between Berina (Whig) and Artander (Tory), while The Cousins has a Spanish setting, and tells how Sebastian is rejected by Elvira in favour of his cousin Lorenzo (McBurney (1959) 354n.). The Cousins: a machine-readable transcript. Cambridge: Chadwyck-Healey, 1996.

The Accomplish'd Rake, or The Modern Fine Gentleman. Being an Exact Description of the Conduct and Behaviour of a Person of Distinction. 1727. Published anonymously according to McBurney (1959) (348n and 350n); the $D N B$ wrongly gives 1756 as the date of first publication, with a different subtitle: Being the genuine Memoirs of a certain Person of Distinction. The Accomplished Rake or Modern Fine Gentleman. Being An Exact Description of the Conduct and Behavior [sic] of a Person of Distinction. 1727 has reached us through W. H. McBurney's edition (1963). Although this edition is not without merit, one misses the valuable data provided by the original orthographic conventions and layout. The Accomplish'd Rake: a machine-readable transcript. Cambridge: ChadwyckHealey, 1996. Source text: The Accomplish'd RAKE: OR, Modern Fine GENTLEMAN. BEING An Exact DESCRIPTION OF THE Conduct and Behaviour OF A PERSON OF DISTINCTION. Whe Conqu'ring Vice Triumphant takes the FIELD, Virtue Dethron'd must to its Pow'r yield; And when Good Characters are all at stake, The Best of Bad Ones is, th'Accomplish'd Rake. Printed in the year M DCC XXVII: And Sold by the Booksellers of London and Westminster, 1727. Vi, $196 \mathrm{p}$.

The False Friend: Or the Treacherous Portugueze. 1732. Pirated by another author (McBurney [1959 \& 1963)]: 354 \& 236n, respectively); Spender (1986: 123) attributes it to Davys.

\section{DRAMA}

The Northern Heiress, Or the Humours of York, A Comedy. 25 Apr. 1716.

The Self Rival, A Comedy. As it should have been acted at the Theatre Royal in Drury Lane. 1725.

\section{POETRY}

The Modern Poet. 1725. A satirical poem. 


\section{B. Eliza Haywood.}

\section{FICTION OF HER FIRST PERIOD}

\section{NOVELS.}

Love in Excess; or, The Fatal Inquiry, a novel. Parts 1 \& 2 1719, Part 3 1720; 5 editions by 1724, Schofield; N.C.B.E.L. at least 9 editions by 1750; Spender: 3rd ed. 1721, 1722, 1724, 6th ed. 1725; Printed for W. Chetwood and J. Roberts, 1719. I have examined the eighth ed. n. d. 12mo, held by the University of Reading Library (no subject entry 15265).

The British Recluse; or, the Secret History of Cleomira, Suppos'd dead. A Novel. London: Printed for D. Browne, Jr., W. Chetwood and Woodman; and S. Chapman, 1722; 3rd ed. Dublin 1724. Spender (108) 2nd ed. 1722, 1724, 1725, 1732, published together with The Injur'd Husband in 1724. N.C.B.E.L., II, 989: 4 eds. said to have been published in 1732 following the text of the first edition of 1722 ; trans. Amsterdam 1770 La recluse angloise; Schofield (120-1) mentions that the novel was written 1722 and dated 1723, adding that she has used the 1732 edition, which was included in the third of Secret Histories, Novels, and Poems. If in fact there was no other edition over the following ten years, the one I have examined, vol. II of Secret Histories, Novels, and Poems, Written by Mrs. Eliza Haywood, 4th Ed. (1742), Printed for R. Ware, in Amen-Corner; S. Birt, in Ave-MaryLane; D. Browne, without Temple-Bar; C. Hitch, in Pater-noster-Row; and S. Austen, in St. Paul's Church-Yard (1742), would be the fifth at most, and not the sixth, even taking account of Spender's information and allowing that the preceding edition was wrongly dated, by accident or design.

The Injur'd Husband; or, The Mistaken Resentment. A Novel. Printed for D. Browne, Jr., W. Chetwood and J. Woodman, and S. Chapman, 1723. Dublin 1724. Spender, 2nd ed. 1723, 1724,1725 . Confusion exists concerning the number of editions published and their respective dates. Schofield (130) mentions 1723 as publication date and says he has used the third edition of Secret Histories... (1732). This does not match the data provided by Spender (108): 2 eds. in 1723, another in 1724, and a further one in 1725. This would mean that if we assume that the fifth ed. is that published in 1742 (the one I have examined: Secret Histories, Novels, and Poems. 4th ed. (1742), Vol. II, Univ. Reading), then the 1732 edition mentioned by Schofield would be missing. Besides this, Spencer, in Todd (158), confirms that the text was published on its own in 1723 and together with other works in 1724 . Other scholars, erroneously in my judgement, give 1724 as the publication date (Beasley, 162).

Idalia, or, The Unfortunate Mistress. A Novel In Three Parts. Printed for D. Browne, Jr., W. Chetwood, and S. Chapman, 1723. Spender 2nd ed. 1723, 1725. Idalie, ou l'Amante infortunée, traduit de l'anglois. Lyon: 1770, 2 parties en 1 vol., Jules Gay, Bibliographie des ouvrages relatifs à l'amour, aux femmes, au marriage et des livres facétieux. N.C.B.E.L.: 4 eds. by 1732, tr. Amsterdam, 1770. Secret Histories, Novels, and Poems, Written by Mrs. Eliza Haywood. 1742. 4th ed.

The Rash Resolve, or, The Untimely Discovery. A Novel, In Two Parts. 1723. DNB 1724. Spender 1724, 2nd ed. 1724); rpt. with Aubin, Mary. Life of the Lady Lucy, introd. Josephine Grieder, New York: Garland, 1973. Schofield claims that the novel was 
published in 1723 and dated 1724, Printed for D. Browne, Jr., and S. Chapman, 1724. I have examined it in Secret Histories, Novels, and Poems. vol. IV 1742. 4th ed., Univ. of Reading.

Lasselia, or, the Self-Abandon'd. A Novel. Printed for D. Browne, Jr., and S. Chapman, 1723. DNB 1724 (Spender 1723, 1724, 1725), Preface in Williams. N.C.B.E.L.: 4 eds. by 1732. Secret Histories, Novels, and Poems 4th Ed. (1742) is held by the Univ. of Reading.

The Force of Nature, or, the Lucky Disappointment. A Novel. 1724. 1725. In Secret Histories, Novels, and Poems. 1742, 4th ed. held by the Univ. Reading.

The Masqueraders; or, Fatal Curiosity. Being the Secret History of a Late Amour. Part 1 1724, Printed for J. Roberts. Spender 3rd ed. 1724, Part 2 1725. N.C.B.E.L. 6 eds. by 1732. Secret Histories, Novels, and Poems.

The City Jilt; or, the Alderman Turned Beau: A Secret History. Printed for J. Roberts, 1726. 2nd ed. 1726 Spender; N.C.B.E.L.: 3 eds. by 1726.

The Double Marriage, or The Fatal Release. 1726 Spender; London: Printed for J. Roberts, 1726, 3rd ed. Schofield.

Cleomelia; or, The Generous Mistress. To Which Is Added, I. The Lucky Rape; or, Fate the Best Disposer. II. The Capricious Lover; or, No Trifling with a Woman. Schofield 1726, dated 1727, 2nd ed. London: Printed for J. Millar and J. Roberts, T. Astley, W. Meadows, J. Mackeuen, H. Northcock, 1727. Histoire de Cléomélie, Nouvelle dans le genre intéressant trad. de l'Anglois de Mlle. Elise Haywood, Bibliothèque Universelle des Romans, 1775-1779, Bibliothèque Nationale, Paris, 1777.

Philidore and Placentia, or L'Amour trop Delicat. A Novel. Schofield: Printed for T. Green and sold by J. Roberts, 1727 Part 1. McBurney (1964) says that the work is described in its title as 'novel' but his edition does not reflect this. Philidore and Placentia Or L'Amour trop Delicat (1727) has reached us through W. H. McBurney's edition of 1973, University of Nebraska Press, which reproduces the original extant in Harvard College Library. As mentioned before, the publication is not an exhaustive critical edition.

The Fair Hebrew; or, a True, but Secret History of Two Jewish Ladies Who Lately Resided in London. 1729. Ascribed to Haywood in an advertisement in Frederick, DNB. Spender 1729, 2nd ed. London: Printed for J. Brindley, W. Meadows, J. Walthoe, A. Bettesworth, T. Astley, T. Worral, J. Lewis, J. Penn, and R. Walker, 1729. Preface in Williams.

Persecuted Virtue, or the Cruel Lover. London: Printed for J. Brindley and sold by W. Meadows and H. Whitridge, T. Worral, R. Franklin, and J. Watson, 1728, Spender and Schofield. 1729 ascribed to Haywood in an advertisement in Frederick, DNB.

The Arragonian Queen, a secret history. Spender 1724, 2nd ed. 1724, London: Printed for J. Roberts; 1727.

The Unequal Conflict; or, Nature Triumphant. London: Printed for J. Walthoe and J. Crokatt, 1725. 1726 Spender.

Fatal Fondness, or Love Its Own Opposer. London: Printed for J. Walthoe and J. Crokatt, 1725. Sequel of The Unequal Conflict.

Mary Stuart, Queen of Scots, Being the Secret History of Her Life. Translated from the French. Mahl supplies a title with variants: Mary, Queen of Scotland. London: Printed for D. Browne, Jr., S. Chapman, J. Woodman, and D. Lyon, 1725. Spender 1725, 1726, 1743. Schofield 2nd ed., London: Printed for D: Browne, Jr. and S. Chapman, J. Woodman, D. Lyon, 1726. Compilation based on 14 or 15 French works (Blain). 
The Distressed Orphan; or, Love in a Mad-house. London: Printed for Sabine and Son, 1726. 3rd ed. Printed for J. Roberts, 1726. Inspired by Middleton's The Changeling. Love in a Madhouse, or The History of Eliza Hartley, the Distressed Orphan. 1770. Spender.

(Memoirs of the Court of Lilliput.) 1727. Only attributed to Haywood in the notes to The Dunciad by Pope, and definitely not one of her works according to Spender.

The Perplexed Duchess; or, Treachery Rewarded: Being some memoirs of the Court of Malfy. N.C.B.E.L.: 2 eds. in 1727, 1728, no connection with Webster's play; intrigues of a scheming parvenue. 1727, 2nd ed. 1727 Spender. Schofield 1727, dated 1728, 2nd ed. London: Printed for J. Roberts, 1728.

The Agreeable Caledonian; or, Memoirs of Signora di Morella, a Roman Lady, Who Made Her Escape from a Monastery at Viterbo, for the Love of a Scots Nobleman. Part 1 1728, Part 2 1729, reprinted as Clementina; or, The History of an Italian Lady, Who Made Her Escape from a Monastery, for the Love of a Scots Nobleman. London: Printed for R. King and sold by W. Meadows, T. Green, J. Stone, J. Jackson, and J. Watson, 1728, 1729. F. \& J. Noble, 1768, Whicher, Spender and Mahl. Rep. New York: Garland, 1973.

\section{DUNCAN CAMPBELL BIOGRAPHIES .}

A Spy Upon the Conjuror, or, A Collection of Surprising Stories with Names, Places, and particular Circumstances relating to Mr Duncan Campbell, commonly known as the Deaf and Dumb Man; and the astonishing Penetration and Event of his Predictions. Written to my Lord --, by a Lady, who for more than twenty years past; has made it her business to observe all Transactions in the Life and Conversation of Mr. Campbell. London: Printed for Campbell \& Burton, 1724, fictionalized epistle. Spender lists two other editions in 1724, 1725. Ballaster mentions it with variations in the title $A$ Spy on the Conjurer, or, A Collection of Surprising and Diverting Stories, with Merry and Ingenious Letters. By Way of the Memoirs of the Famous Mr. Duncan Campbell. Revised by Mrs. Eliza Haywood. London: 1724. Thomas Finlayson Henderson in DNB, in the entry on Campbell, thinks that, although the work was attributed to Haywood, "there is every reason to suppose that the real author was Daniel Defoe, Campbell supplying him with the necessary information." $\mathrm{S}$. Lee in the article on Haywood, $D N B$, attributes it unreservedly to Haywood. L. Stephen, $D N B$, in Defoe's biography does not mention this work at all. Schofield considers that the text was written by Haywood and Defoe. The latter, with a very minor collaboration by Haywood, had earlier written The History of the Life and Adventures of Mr. Duncan Campbell, a gentleman who, though deaf and dumb, writes down any strange name at first sight, with their future contingencies of fortune. Now living at Exeter Court over against the Savoy in the Strand. 2nd ed. London: Printed for E. Curll, 1720.

The Dumb Projector: Being a Surprizing Account of a Trip to Holland made by Mr Duncan Campbell. With the Manner of his Reception and Behaviour there. As also the various and diverting Occurrences that happened on his Departure. London: Printed for W. Ellis, J. Roberts, Mrs. Billingsley, A. Dodd, and J. Fox, 1725. Epistolary story written by Haywood and Daniel Defoe in collaboration.

The Friendly Daemon. 1726. Repr. as Secret Memoirs of the Late Mr Duncan Campbell. Printed for J. Millan and J. Chrichley 1732, Schofield. 


\section{NOVELETTES.}

The Surprise, or Constancy Rewarded. Printed for J. Roberts, 1724. DNB 1724. Spender 1724, 1725.

The Fatal Secret; or, Constancy in Distress. London: Printed for J. Roberts, 1724,. DNB 1725. Spender 2nd ed. 1724. N.C.B.E.L.: 4 eds. by 1732. Secret Histories, Novels, and Poems.

Fantomina, or, Love in a Maze. Being a Secret History of an Amour Between Two Persons of Condition. 1724. DNB. London: Printed for D. Browne, Jr., and S. Chapman, 1725. N.C.B.E.L.: 1725 .

Memoirs of the Baron de Brosse, who was Broke on the Wheel in the Reign of Lewis XIV. Part 1 1725. Apparently never completed (Spender). Schofield 1724, though dated 1725, London: Printed for D. Browne, and S. Chapman, 1724, 1726.

Reflections on the Various Effects of Love, according to the Contrary Dispositions of the Persons on Whom It Operates. London: N. Dobb, 1726. 2nd ed. 1726, 1727. Secret history similar to Haywood's Utopia (Spender).

The Mercenary Lover, or The Unfortunate Heiresses. Being a True, Secret History of a City Amour, In a Certain Island adjacent to the Kingdom of Utopia. Written by the Author of the Memoirs of the Said Island. London: N. Dobb, 1726. 2nd ed. 1726; 3rd ed. 1728 together with The Padlock, or No Guard Without Virtue. Mahl. Facsimile ed. of a copy extant in Yale University Library (IK H336 726), published in New York: Garland, 1973 in the colection Foundations of the Novel, together with other texts by Mary Davys, with an Introduction by Josephine Grieder. This text, originally printed by "N. Dobb in the Strand: And sold by the Booksellers of London and Westminster. [Price One Shilling]," contains elements found in the scandal chronicles for which the novelist was famous, as the title that announces the text shows.

The Padlock; or, No Guard Without Virtue. 1728. In The Mercenary Lover, 3rd ed. Printed for N. Dobb, 1728.

Letters from the Palace of Fame, Written by a First Minister in the Regions of Air, to an Inhabitant of This World. Translated from an Arabian Manuscript. Spender 1727. Schofield London: Printed for J. Roberts, 1726, dated 1727.

The Fruitless Enquiry. Being a Collection of Several Entertaining Histories and Occurrences, Which fell under the Observation of a Lady in her Search after Happiness. London: Printed for J. Stephens, 1727. DNB supplies the whole title, the dedication to Lady Elizabeth Germain and the date 1747. Mahl London: T. Lowndes, 1767. Abridged in Elizabeth Griffith ed. A Collection of Novels, Selected and Revised by Mrs. Griffith. 3 vols. London, 1777, ii. 161-269. N.C.B.E.L.: 5 eds. by 1800.

Irish Artifice; or, The History of Clarina. 1728. Included in The Female Dunciad. 1728 ed. Edmund Curll, London: Printed for T. Read: 17-41; in 2 letters.

The Adventures of Eovaii, Princess of Ijaveo. A Pre-Adamitical History. Interspersed with a Great Number of Remarkable Occurrences, which happened, and may again happen, to several Empires, Kingdoms, Republics, and particular Great Men ... Written originally in the Language of Nature (of Later Years but Little Understood). First translated into Chinese, at the Command of the Emperor, by a Cabal of Seventy Philosophers; and Now Retranslated into English by the Son of a Mandarin, residing in London. London: Printed 
for S. Barker, 1736; repr. New York: Garland, 1973; an attack on Walpole and dedicated to his opponent, Widow Duchess of Marlborough, whom Haywood had earlier harshly criticised in Memoirs of a Certain Island Adjacent to the Kingdom of Utopia. 1725.

The Unfortunate Princess [of ljaveo], interspersed with several curious entertaining Novels. London: 1741, revision of the former with a new title, Spender and DNB. Mahl, London: James Hodges, 1741. Schofield 1740, dated 1741.

The Unfortunate Princess, Or The Ambitious Statesman, Containing the Life and Surprising Adventures of the Princess of Ijaveo. With a frontispiece. London: 1741, BL, Block.

Love Letters on all occasions. Lately passed between persons of Distinction, London: Printed for J. Brindley, R. Willock, J. Jackson, J. Penn, and F. Cogan 1730, DNB, Spender, and Mahl. N.C.B.E.L.: "Collection ranging in scope from single narrative letters to short letter novels."

Dalinda; or, The Double Marriage. London: Printed for C. Cobett and G. Woodfall, 1749, Lockwood and Whicher.

A Present for Women addicted to Drinking, London: W. Owen, 1750, Mahl.

\section{SCANDAL CHRONICLES.}

The Bath-Intrigues: in Four Letters to a Friend in London. Schofield 1724 but dated 1725; 2nd ed. London: Printed for J. Roberts, 1725. 3rd ed. 1725 (Spender). N.C.B.E.L.: 3 eds. by 1725.1725 copy in Clark Library, U. of California Los Angeles. Brown U. Women Writers Project. Internet. 15 Dec. 1986.

Memoirs of a Certain Island Adjacent to the Kingdom of Utopia. Written by a Celebrated Author of that Country. Now Translated into English. London: Printed, and Sold by the Booksellers of London and Westminster, 1725. Spender vol. 1 1725, Vol. 21726. Schofield vol. 1 1724, vol. 2 1725. 2nd ed. 1726. Rep. New York: Garland, 1972, Introd. Josephine Grieder, reproducing the text extant in Beinecke Library, Yale Univ. (IK H336 $725 \mathrm{M}$ ).

The Secret History of the Present Intrigues of the Court of Caramania. London: Printed: and Sold by the Booksellers of London and Westminster, 1727. Spender, 2nd ed. 1727 with a key. Schofield mentions The Court of Carimania [sic]. 1726, dated 1727. Rpt. New York: Garland, 1972, ed. J. Grieder from the copy (IK H336 727S) extant in Beinecke Library, Yale University.

(Some Memoirs of the Amours and Intrigues of a Certain Irish Dean). 1728. Criticism of Swift (Blain).

Letters from the Palace of Fame. 1727. Epistolary, N.C.B.E.L.

\section{LATER NOVELS AND STORIES.}

Anti-Pamela, or Feign'd Innocence Detected in a Series of Syrena's Adventures. 1741. Schofield says that is was published by Haywood in 1741, 2nd ed. London: Printed for F. Cogan, 1742. 1742 Spender. N.C.B.E.L.: 2 eds. in 1741, authorship not confirmed. Rpt. New York: Garland, 1975. 
The Fortunate Foundlings, being the Genuine History of Colonel M-rs and His Sister Madame de P--y, the issue of the Hon. Ch-s. M-rs, Son of the Late Duke of R-l-d. Ballaster London: 1741. N.C.B.E.L., Block \& Mahl, London: Printed for T. Gardner, 1744, Cambridge Univ. Library. Dublin: Printed for A. Bradley, 1744, Schofield. 3rd ed. May 1748 announced in April in Life's Progress, 4 eds. by 1761. C. P. J. de Crébillon Fils (writer's wife), Les heureux orphelins, histoire imitée de l'anglois. Paris: 1754 Kent \& Hughes. There is another version, The Happy Orphans, An Authentic History of Persons in High Life. With a Variety of Uncommon Events, and Surprising Turns of Fortune. Translated and improved from the French original. Trans. Edward Kimber from Crébillon's French version, 1758, 1759 Hughes. N.C.B.E.L.: 1759, 3 eds. by 1770 , rpt. New York: Garland, 1974.

(Leonora, or Characters Drawn from Real Life. 1744, Spender).

Life's Progress Through the Passions, or The Adventures of Natura, By The Author of The Fortunate Foundlings. London: Printed for T. Gardner, and sold at his Printing-Office, at Cowley's Head, opposite St Clement's Church, in the Strand, April 2, 1748. BL, Illinois Univ. Library Facsimile rpr. (x823.H331) New York: Garland, 1974. Allegory.

A Letter from H[enry] G[orin]g Esq., one of the Gentlemen of the Bed-Chamber to the Young Chevalier. London: Printed and sold at the Royal Exchange, Temple-Bar, Charing Cross, and all the Pamphlet Shops of London and Westminster, 1750. Monthly Review, BL, Black. Trans. into French, Lettre de H... G...g, écuyer. 1757 N.C.B.E.L., Spender.

The History of Cornelia. London: Printed for A. Millar, 1750.

The History of Miss Betsy Thoughtless. 4 vols. Mahl \& Orr, London: Printed for T. Gardner, 1751. Dublin 1751, 1765, 1768, 1783, Spender. Novelist's Magazine, vol. XIII, 1, 1 part, Sept. 13- Oct 31, 1783, 312 pp., copy Univ. of Reading Library and BL. Black, at least 8 eds. by 1800 , copy in Harvard College Library. Princeps edition Illinois Univ. Rpr. London: Pandora Press (Routledge \& Kegan Paul) 1986, Introd. Dale Spender, collection Mothers of the Novel. The efforts made by the publishers to popularize women's writings of the eighteenth and nineteenth centuries is laudable since, in most cases, the texts had not been reissued. However, the contribution does not extend much further than exhuming the texts, which are published together with an introduction by a contemporary female reader. One wishes they had undertaken a thorough task of editing and annotation as a guide for the reader, though this would have exceeded the stated purpose of this feminist collection. However, it would surely not be too onerous for them to indicate at least the origin of the text published. New York: Garland, 1979. L'étourdie, ou, L'Histoire de Miss Betsy Tatless. Traduite de l'anglois (de Mrs. Eliza Haywood par le Chevalier de Fleurian), 4 vols., Paris: Prault l'aîné, 1754, Bibliothèque Universelle des romans, 1775-1789, Bibliothèque Nationale, Paris. The Coquette or the Mistakes of the Heart. 1777 play, adaptation from the novel, Blondel.

The History of Jemmy and Jenny Jessamy. 3 vols. London: Printed for T. Gardner, 1753. British Library; Dublin 1753, 1769. Reissued February 5-March 12, 1785 Novelist's Magazine, XVII, 3, 1 part, 226 pp., Univ. of Reading Library, BL. Schofield 1752, dated 1753. Black mentions the existence of a 1753 copy in Harvard College Library. Epistolary. rpt. New York: Garland, 1974. 
Modern Characters, Illustrated by Histories in Real Life, and Addres'd to the Polite World. 2 vols. London: Printed for T. Gardner, 1753. Van Pelt Library Univ. of Pennsylvania, Blondel.

The Invisible Spy. publ. 1754 dated 1755. 2 vols. Block: 4 vols., London: T. Gardner, 1755, by Exploralibus. Black: 6 eds. by $1800.1755,1759,1766,1773,1778$ Spender. Schofield: The Invisible Spy. By Exploribus [sic] London: Harrison and Co., 1755 \& Printed for T. Gardner, 1755. The Invisible Spy. By Explorabilis [sic], Novelist's Magazine, vol. XXIII, 6, Jul. 1-Oct. 1, 1788, 1 part, 235 pp. Epistolary. An abridged version of this text in Gentleman's Magazine, XXIV (Dec., 1754), Mayo.

(Matrimony. 2 vols. 1755). Spender.

The History of Leonora Meadowson. 1778, 3? vols. DNB.

\section{ESSAYS AND FICTION IN PERIODICALS.}

The Tea Table To Be Continued every Monday and Friday. No. 1-36, 21 Feb-22 Jun., 1724, 36 issues, BL, N.C.B.E.L. Not to be confused with The Tea-Table: or, A Conversation between some Polite Persons of both Sexes, at a Lady's Visiting Day. Wherein are represented the Various Foibles, and Affectations, which form the Character of an Accomplish'd Beau, or Modern Fine Lady. Interspersed with several Entertaining and Instructive Stories. London: Printed for J. Roberts, 1725. Extract in Williams attributed to Haywood. Spender Part 1 1725, 4th ed. 1725, Part 2 1726, published as an appendix to Letters from a Lady of Quality to a Chevalier, and in which some 'novellas' are interspersed, Schofield. Essay on modern manners by way of a conversation between a lady and her visitors.

The Female Spectator (April 1744- May 1746), 24 monthly issues. Later in 4 vols. London: T. Gardner, 1746, Mahl. London and Dublin, 1746. London 1748, 1750. 5th ed. 1755 Univ. of Reading Library. 1766 N.C.B.E.L. 7th ed. 1771, Spender. Announced in 12mo and 8 vo by T. Gardner, in the 1748 April edition of Life's Progress Through the Passions. La Spectatrice, ouvrage traduit de l'anglois (d'Eliza Haywood par J. A. Trocheneau de la Berlière). Paris: Rollin fils, 1751. 2 tomes en 1 vol. Bibliothèque Nationale, Paris. To the best of my knowledge there is no contemporary edition of the text, except for the electronic edition by Brown Univ. Women Writers Project. This outstanding labour of textual archaeology is an attempt to provide students and scholars with hundreds of texts which would otherwise be inaccessible and may serve as a basis for future editions. I have also examined a rpt. of selections: Mary Priestley (ed.), The Female Spectator. Being selection's from Mrs. Eliza Heywood's [sic] Periodical. London: John Lane, The Bodley Head, 1929. The selection was made by Mary Priestley and it includes an introduction by J. B. Priestley, but the approach is devoid of philological method and the literary analysis, from the perspective of the end of the twentieth century, seems anecdotal and outdated. There are other editions of excerpts of texts that set the work within the framework of a women's literary tradition. One of them (Mahl) echoes the publication in its very title. The second includes an ample selection of fragments by Dale Spender and Janet Todd entitled British Women Writers. An Anthology from the Fourteenth Century to the Present. New York: Peter Bedrick Books, 1979. The last one is ed. by P. M. Spacks, London: Bristol 
Classical Press, 1993. Selections from The Female Spectator. Oxford: O.U.P. \& Women Writers Project, 1998.

The Parrot. 4 issues 25 Sept- 16 Oct. 1728. The Parrot, with a Compendium of the Times. (2 Aug.- 4 Oct. 1746), weekly, 9 issues, 2nd series. London: Printed for T. Gardner, 1746. N.C.B.E.L.: written in collaboration.

The Young Lady. Jan. 1756, 3 issues, Spender.

\section{CONDUCT BOOKS.}

A Present for a Servant-Maid; or, the Sure Means of Gaining Love and Esteem. 1741 DNB. Dublin: George Faulkner, 1743; 1744, 1745, A New Present for a Servant Maid, 1772, Spender. Schofield, Printed for T. Gardner, 1743.

The Wife, by Mira one of the Authors of The Female Spectator. London: Printed for T. Gardner, 1756. BL, 282 pp. 1756, 1762 Spender. 1755 MacCarthy. Schofield 1755, dated 1756.

The Husband. In Answer to the Wife. London: Printed for T. Gardner, 1756, Mahl, BL. Epistles for the Ladies. Dated 1749-50 Schofield, London: Printed for T. Gardner. 2 vols. DNB claims to have taken the reference from Watt's Bibli. Brit. Spender, 1749, 1753, London: Printed for H. Gardner, 1776. Mahl, London: T. Gardner, 1729. Black explains that the first vol. appeared in 1748 , dated 1749 , and mentions three later editions, B.L.

\section{TRANSLATIONS.}

Bursault. Ten Letters from a Young Lady of Quality. 1720. Bell et al., and Spencer in Todd ed. Haywood's only work published by subscription. $D N B$ and Spender Letters from a Lady of Quality to a Chevalier. Translated from the French. 1724. Schofield mentions the work under the latter title and says it was published 1720, although dated 1721, Printed for W. Chetwood. Day: 2nd title, 1721. Trans. freely from Boursault, epistolary and with a theoretical preface on this type of texts. Her only play by subscription, Blain. 2nd ed. London, 1724, Ballaster.

The Life of Madam de Villesache, written by a lady, who was an eye-witness of the greatest part of her adventures. Mahl and Schofield: London: Printed for W. Feales and J. Roberts, 1727. Trans. from French, Spender. N.C.B.E.L.: probable trans. from an unidentified French source.

The Disguis'd Prince; or, the Beautiful Parisian. A True History ... Mahl, 2 pts. London: Printed for T. Corbett and sold by J. Roberts, 1728. Pt. 1, 1728 Schofield. Trans. from French, 1763, Madame de Villedieu, L'Illustre parisienne. 1679. Pt. 2 1733, Spender. Schofield Pt. 2 1729. Preface in Williams.

La Belle Assemblee, or The Adventures of Six Days. Being a Curious Collection of Remarkable Incidents which happen'd to some of the First Quality in France. Pts 1,2 \& 3 (making up vol. 1) 1724, vol. 21726 according to Spender. Schofield: 2nd ed. London: Printed for D. Browne, Jr. and S. Chapman, 1725. DNB: La Belle Assemblée, a curious collection of some very remarkable incidents which happened to Persons of Quality; translated from the French of Mdme. de Gomez, Les journées amusantes. 1732. 4th ed? 
4 vols., 1724-26. Mahl, 2 vols. London: D. Browne et al., 1724, also published as Poisson de Gomez. N.C.B.E.L., 8 eds. by 1765.

L'Entretien des Beaux Esprits. Being the Sequel to La Belle Assemblée. Contains 12 novels, 1734, 2 vols., dedicated to Charles Seymour, Duke of Somerset. London: Printed for F. Cogan and J. Nourse, Spender, $D N B$, Schofield, BL.

The Lady's Philosopher's Stone, or The Caprices of Love and Destiny: an Historical Novel. London: Printed for D. Browne, Jr. and S. Chapman, 1725, Schofield. Historical novel trans. from French, Lois Adrien Duperron de Castrera, La Pierre philosophale des dames, ou Les Caprices de l'amour et du destin. 1723.

Love in its Variety. 1727, 1767, trans. from Spanish (Spender). London: Printed for W. Fearles and J. Jackson, 1727. Schofield, trans. from the work by Matteo Bandello. N.C.B.E.L.: 6 novels, which are said to be a trans. from Bandello, but they are probably originals or free adaptations.

Mrs Haywood's Select Collection of Novels and Histories, Written by the Most Celebrated Authors, in several languages. All Newly translated from the originals, by several hands. 6 vols., 1729, Spender.

The Busy Body, or Successful Spy. 1741. Trans. from French, adaptation from De Mouhy, La Mouche, ou Les Aventures et espiègleries facétieuses de Bigand. 1736, 1741, Elwood. 1742 Foster and N.C.B.E.L. Schofield says that the trans. was ed. by Haywood in 1741, 2 vols. London, 1752.

The Virtuous Villager, or The Virgin's Victory. Mahl, 2 vols. London: Printed for Francis Cogan, 1742. Trans. from French Charles de Fieux, chevalier de Mouhy, La Paysanne Parvenue. The latter adapted from Marivaux, La Vie de Marianne. Block: The Famous Villager, or The Virgin's Victory; being memoirs of a very great lady at the Court of France, Written By Herself. Translated from the original [or rather rewritten] by the author of La Belle Assemblée, 2 vols., London, 1742, BL, rptd. New York: Garland, 1975.

\section{DRAMA.}

The Fair Captive. A Tragedy. Performed Lincoln's Inn Fields 4 March 1721. N.C.B.E.L. revision of an unpublished piece by Captain Hurst, London: Printed for T. Jauncy and H. Cole, 1721.

A Wife to Be Lett: A Comedy. Performed Drury Lane 12 August 1723, Printed for D. Browne, Jr., and S. Chapman; N.C.B.E.L. 1724, 1724, 1729, 1735.

Frederick, Duke of Brunswick-Lunenburgh. A Tragedy. Performed Lincoln's Inn Fields 4 March 1729. Immediately published with a dedication to Frederick, Prince of Wales, denying any relation with contemporary politics. Spender: 2nd ed. 1729. Dublin 1729. London: Printed for W. Mears and J. Brindley, 1729.

The Opera of Operas; or Tom Thumb the Great ... set to music ... by Thomas Arne. Performed Haymarket and Drury Lane, 31 March 1733, 31 May 1733, N.C.B.E.L., anonymous, attributed to Haywood, libretto in collaboration with William Hatchett, adaptation of Henry Fielding's The Tragedy of Tragedies; or, The Life and Death of Tom Thumb the Great. Printed for W. Rayner, 1733, Shattock.

Plays and Short Fiction. P. Backsheider, ed. Oxford: O.U.P. \& Women Writers Project, 1988. 


\section{POETRY.}

Poems on Several Occasions. 1724, DNB, Spender 1724, 1725.

\section{ANTHOLOGIES.}

The Works of Mrs. Eliza Haywood; Consisting of Novels, Letters, Poems, and Plays. 4 vols.

- London: Printed for Dan. Brown, Jr. and Sam. Chapman, 1724. Schofield states that the three first vols. were published in 1723 and the fourth in 1724. N.C.B.E.L.: rpt. 4 vols.

I. Love in Excess.

II. The British Recluse. The Injur'd Husband. The Fair Captive.

III. Idalia. Letters from a Lady of Quality.

IV. Lasselia. The Rash Resolve. A Wife to Be Lett. Poems on Several Occasions.

Secret Histories, Novels and Poems. 2 vols. London: D. Browne et al., 1724, Mahl.

Secret Histories, Novels and Poems. 4 vols. 1725, 1732; 4th ed. 1742 London: Ware, Birt,

Browne, Hitch, Austen, N.C.B.E.L.

I. Love in Excess.

II. The British Recluse. The Injur'd Husband. Poems on Several Occasions.

III. Idalia. The Surprise. The Fatal Secret. Fantomina.

IV. The Rash Resolve. The Masqueraders. Lasselia. The Force of Nature.

Secret Histories, Novels and Poems. 2 vols. 1725. Vol. I is a replica of vol. III and vol. II of vol. IV (Spender).

Secret Histories, Novels, etc...' printed since the publication of the four volumes of her works'. 1727, 2 vols. Spender.

I. The Distressed Orphan. The City Jilt. The Double Marriage. Letters from the Place of Fame. The Lady's Philosopher's Stone.

II. Memoirs of the Baron de Brosse. Bath Intrigues. The Masqueraders. Part 2; The Perplexed Duchess.

Several of Eliza Haywood's novels were included in Elizabeth Griffith, Collection of Novels. 1771, Spender. Some, such as The Fruitless Enquiry, II, 161-269, abridged according to Ballaster.

\section{SARAH FIELDING.}

The Adventures of David Simple, Containing an Account of his Travels through the Cities of London and Westminster in the Search of a Real Friend, By a Lady. London: Harrison, 1744. N.C.B.E.L.: Vols. 1 \& 2 rev. Henry Fielding 1744. 3 Vols. 1744-53; 5 Vols. Dublin 1761; 1775 2nd ed. abridged [Schlueter]; 3 more eds. by 1792. In Novelist's Magazine, Vol. IX (3) 1793. 157 pp. BL. Ed. \& Introd. Malcolm Kelsall, London: O.U.P., 1969, publ. in paperback 1987 with a bibliographic revision, rpt. 1994.

Le Véritable ami, ou la Vie de David Simple. Trans. Skunk [P.-A. de La Place], Amsterdam, 1749. N.C.B.E.L.: 4 vols. 1751. 2 vols. In 1 vol. in-12 $\mathrm{BN}$, Bibliothèque universelle des romans, $1775-1789$.

Familiar Letters Between the Principal Characters in David Simple; to which is added $A$ Vision, London: Millar, 1747, 2 vols., BL. This is Vol. II of David Simple, according to 
Spender and others. Extract from the Preface "Written By a Friend of the Author" in Barnett ed. 56-58, contribution by Henry Fielding. N.C.B.E.L.: 2nd ed. 1752.

The Governess; Or, The Little Female Academy: Calculated for the Enterntainment and Instruction of Young Ladies in their Education. By the Author of David Simple. 12mo. London: 1749, rpt. 1751, 1768, 1870. It appears under this epigraph in Fielding's Cleopatra \& Octavia, xiii., BL. Ed., Introd. \& Bibliog., Jill E. Gray, London \& Oxford: O.U.P., 1968, facsimile of the 1st ed. The Governess; or [the] Little Female Academy: Being the History of Mrs Teachum and her Nine Scholars. Introd. Mary Cadogan, London \& New York: Pandora, 1987. The unstable subtitle, with 'Girls' sometimes replacing 'Scholars', appears after the Preface of this edition as an alternative title for the text itself. N.C.B.E.L.: at least 7 eds. by 1800 . In Cruse: 80,92 , it is attributed to Mrs Sherwood. N.C.B.E.L.: restructured by Sherwood in 1820.

Remarks on Clarissa. 1749. Introd. Peter Sabor, Los Angeles: William Andrews Clark Memorial Library, U. of California, 1985, Augustan Reprint Society Publication.

(The History of Betty Barnes. 2 vols., London: D. Wilson \& T. Durham, 1753, BL. N.C.B.E.L.: Betsy Barnes tr. [Eidous], 2 vols., n. d.).

and Collier, Jane. The Cry: A New Dramatic Fable. 3 vols., London: R \& J. Dodsley, 1754, BL. Preface in Barnett ed.: 102-108. The preface is attributed exclusively to S. Fielding.

The Lives of Cleopatra and Octavia. London: Printed for the Author, 1757, BL, Cambridge Univ. Library. Block 1754. 2nd ed. London: Millar, 1758. n. p. [London]: The Scholartis Press, 1928, Ed. \& introd. By the great early-century specialist in women's narrative, R. Brimley Johnson. It carries no reference to the original reproduced.

The History of the Countess of Dellwyn, By The Author of David Simple. 2 Vols., London: Millar, 1759, BL. 2 vols. rptd. in One, New York \& London: Garland, 1974, facsimile reproduction of the copy extant in the Library of the Univ. of Illinois (823.F465h). Bristol: Thoemmes Press, 1994, Introd. Linda Bree.

The History of Ophelia. Published by the Author of David Simple. 2 vols., London: Printed for R. Baldwin, at the Rose, in Pater-Noster-Row, 1760. Novelist's Magazine, London, Harrison, Vol. XIX (3), 1785, 2 vols. in 1: 133 pp., BL. 1787. Facsimile edition of a copy in the Library of the Univ. of Illinois (x823.F465hi) Two Vols., rpt. in One, New York \& London: Garland, 1974.

Ophélie, roman traduit de l'anglois (par Mme. Belot, later présidente Mme. Durey de Meynières), 2 vols., Amsterdam, 1763, in-12. Barbier, A., Dictionnaire des ouvrages anonymes. Halkett \& Laing, A Dictionary of the Anonymous and Pseudonymous Literature of Great Britain. Grimm-Diderot, Correspondance littéraire, philosophique et critique.

Xenophon's Memoirs of Socrates, with the Defence of Socrates before his Judges. Trans. from the Original Greek by Sarah Fielding, 1762.

The Whole Works of Xenophon, Trans. Ashley, Cooper, Spelman, Smith, Fielding \& others: Jones, 1832. (Memorabilia. The Apologia.) 


\section{FRANCES SHERIDAN.}

\section{FICTION.}

A Letter from a Young Lady to Mr. Cibber. 1743; in Cibber and Sheridan.

The Owls: A Fable. 1743; in Dublin News Letter.

The Memoirs of Miss Sidney Bidulph. Extracted from her own Journal, and now first published. 3 vols., anon., London: R. \& J. Dodsley, Faulkner, March 1761, Dublin. 2nd ed. rev. London: Dodsley, July 1761. London: 3rd ed. 5 vols. 1767 expanded. 3 vols. 1767. 1 vol. Novelist's Magazine, vol. XXII (2) 1786, vi+402 pp., Blondel: "comprenant Conclusion of the Memoirs of Miss Sidney Bidulph. 1767“, BL. 4th ed. 1772, 5 vols. 5th ed. 5 vols. 1796. Memoirs of Miss Sidney Bidulph. Extracted from her own Journal, and now first published. Introd. Sue Townsend, London: Pandora, 1987. This text clearly illustrates the lack of thorough scholarship behind some editions of texts by women writers, thus exemplifying the neglect from which this type of narrative has suffered in the past. Since the nineteen-seventies and eighties, these texts have been published with the aim of bringing them to the attention of a wider readership, but they stand in need of editing and annotation. The first edition to become available in this case was that published by Pandora. In it, as has already been indicated for other texts by the same publisher, there is no bibliographical reference whatsoever to the original edition being reproduced. In 1995 Patricia Köster and Jean Coates Cleary prepared a new edition, published by OUP, that reproduces the second issue of July 1761 from the extant copy in the Univ. of Toronto. This impeccable edition offers an introduction, notes, a bibliographical account of the text, a general bibliography, and a chronology of the writer's life. From this textual history we learn that the Pandora edition reproduces the first edition of March 1761 in vols. I and II and the second, of July, in vol. III.

Mémoirs de Miss Sidney Bidulph, 3 vols., trans. [J. B. R. Robinet], Amsterdam, 1762.

Mémoirs por servir à l'histoire de la vertu, trans. [A. F. Prévost], Cologne (for Paris), 1762. L'habitant de Guadeloupe, trans. 1762. German trans., 1762.

The History of Nourjahad. By the Editor of Sidney Bidulph. London: Dodsley, 1767, 240 pp., BL. 1788, 1827, 1828. Rep. London: Elkin, Matthew \& Marrot, 1929, Ed. \& Introd. H. V. Marrot, Ilustr. Mabel R. Peacock. In Spender \& Todd eds.: 248-94. In Oriental Tales, ed. Robert L. Mack, Oxford: OUP, 1992, reproducing the 1st ed.

Nourjahad: histoire orientale. tr. [Mme de Sérionne], Frankfurt 1769, another tr.? 1785, tr. Polish 1784.

Eugenia and Adelaide. 2 vols., London: Dilley, 1791

Letters and Ode to Patience. 1799; In A Miscellany.

\section{DRAMA.}

The Discovery: A Comedy in Five Acts. 3 Feb. 1763, Drury Lane, 1763, 2nd ed. 1763, London, Dublin 1763, Edinburgh 1763, Larpent ms., adapted for the modern stage by Aldous Huxley, Royal Academy of Dramatic Art, 4 May 1924, NCBEL.

The Dupe. Comedy, Drury Lane, 10 Dec. London: Millar, 1763, 1764, Larpent ms. 
A Trip to Bath. 1765, Comedy unacted, ed. F. Rae, Sheridan's Plays as he wrote them (1902), [emphasis mine]. Rae's text $A$ Journey to Bath is apparently an incomplete revision by another hand, possibly R. B. Sheridan c. 1774 NCBEL.

The Plays of Frances Sheridan. Ed. \& Introd. Robert Hogan \& Jerry C. Beasley, Cranbury, N.J.: Associated University Presses, 1984.

\section{POETRY.}

Verses on Thomas Sheridan. In Sheridan, ed. W. Sichel (1909).

\section{WORKS CITED.}

Backsheider, Paula. "Eliza Haywood," Todd, J. ed. 1987.

Ballaster, Ros. Seductive Forms. Women's Amatory Fiction from 1684 to 1740. Oxford: Clarendon P., 1992.

Barnett, George L. ed. Eighteenth-Century British Novelists on the Novel. New York: Appleton-Century-Crofts, 1968.

Beasley, Jerry C. Novels of the 1740s. Athens: The U. of Georgia P., 1982.

Bell, Maureen, Parfitt, George and Shepherd, Simon. A Biographical Dictionary of English Women Writers 1580-1720. New York: Harvester Wheatsheaf, 1990.

Black, Frank Gees. The Epistolary Novel in the Late Eighteenth Century. A Descriptive and Bibliographical Study. Eugene: U. of Oregon P., 1940.

Blain, Virginia, Clements, Patricia, and Grundy, Isobel. The Feminist Companion to Literature in English. Women Writers from the Middle Ages to the Present. London: B. T. Batsford, 1990.

Block, Andrew. The English Novel 1740-1850. A Catalogue Including Prose Romances, Short Stories, and Translations of Foreign Fiction. Introds. J. Crow and E. A. Baker. London: Dawsons of Pall Mall 1939, rev. eds. 1961, 1963.

Blondel, Madeleine. Images de la femme dans le roman anglais de 1740 à 1771.2 vols. Lille: Université, 1976.

The British Library Eighteenth-Century Catalogue: BL.

The Compact Edition of the Dictionary of National Biography. Complete Text Reproduced Micrographically. 2 vols. London: Oxford U. P., 1975.

Cruse, Amy. The Englishman and His Books in the Early Nineteenth Century. London: George G. Harrap, 1930.

Day, Robert Adams. Told in Letters. Epistolary Fiction Before Richardson. Ann Arbor: U. of Michigan P., 1966.

Elwood, John R. "The Stage Career of Eliza Haywood." Theatre Survey 5 (Nov. 1964):107116.

Foster, James R. A History of the Pre-Romantic Novel in England. New York: M. L. A., 1949. New York: Klaus Reprint, 1966.

Hughes, Helen Sard. "Notes on Eighteenth-Century Fictional Translations." Modern Philology 17 (1920): 225-31.

Kent, J. P. "Crébillon Fils, Mrs. Eliza Haywood and Les Hereux Orphelins: A Problem of Authorship.” Romance Notes XI, 1 (1969): 326-332. 
Lockwood, Thomas. "Eliza Haywood in 1749: Dalinda, and her Pamphlet on the Pretender." $N \& Q, 36,4$ (1989): 475-7.

Lonsdale, Roger ed. Eighteenth-Century Women Poets. An Oxford Anthology. Oxford: Oxford U. P., 1989.

MacCarthy, Bridget G. Women Writers. Their Contribution to the English Novel, 1621 to 1744. Cork: Cork U. P., 1944.

Mahl, Mary R. and Koon, Helene eds. The Female Spectator. English Women Writers before 1800. Bloomington \& London: Indiana U. P. \& New York: The Feminist Press, 1977.

Mayo, Robert D. The English Novel in the Magazines 1740-1815. Evanston: Northwestern U. P., 1962.

McBurney, William Harlin. "Mrs Mary Davys: Forerunner of Fielding." PMLA 74 (1959): 348-55. ed. Four Before Richardson. Selected English Novels 1720-1727. 1963. Lincoln: U of Nebraska P, 1964.

Morgan, Fidelis. Women Playwrights on the London Stage 1660-1720. London: Virago, 1981. Orr, Leonard. A Catalogue Checklist of English Prose Fiction 1750-1800. Troy, New York: The Whitson Publishing Company, 1979.

Schlueter, Paul, and Schlueter, June eds. An Encyclopaedia of British Women Writers. New York: Garland, 1988.

Schofield, Mary Anne. Eliza Haywood. Boston: Twayne, 1985.

Shattock, Joanne. The Oxford Guide to British Women Writers. Oxford: O. U. P., 1993.

Spencer, Jane. "Haywood, Eliza [Fowler] (1693-1756)." In Todd, Janet (ed.) A Dictionary of British and American Women Writers 1660-1800. 157-160.

Spender, Dale. Mothers of the Novel. 100 Good Women Writers before Jane Austen. London: Pandora, 1986.

- and Todd, Janet eds. British Women Writers. An Anthology from the Fourteenth Century to the Present. New York: Peter Bedrick Books, 1989.

Todd, Janet ed. A Dictionary of British and American Women Writers 1660-1800. London: Methuen, 1987.

Watson, George ed. The New Cambridge Bibliography of English Literature. 5 vols. Cambridge: Cambridge U. P., 1971.

-Whicher, George Frisbie. The Life and Romances of Mrs Eliza Haywood. New York: Columbia U. P., 1915.

Williams, Ioan ed. Novel \& Romance 1700-1800: A Documentary Record. London: R. K. P., 1970. 